Contract No. and Disclaimer:

This manuscript has been authored by Savannah River Nuclear Solutions, LLC under Contract No. DE-AC09-08SR22470 with the U.S. Department of Energy. The United States Government retains and the publisher, by accepting this article for publication, acknowledges that the United States Government retains a non-exclusive, paid-up, irrevocable, worldwide license to publish or reproduce the published form of this work, or allow others to do so, for United States Government purposes. 


\title{
RADIATION DOSE ASSESSMENT FOR THE BIOTA OF TERRESTRIAL ECOSYSTEMS IN THE SHORELINE ZONE OF THE CHERNOBYL NUCLEAR POWER PLANT COOLING POND
}

\author{
Boris Ya. Oskolkov, ${ }^{*}$ Mikhail D. Bondarkov, ${ }^{*}$ Sergey P. Gaschak, ${ }^{*}$ Andrey M. \\ Maksimenko, ${ }^{*}$ Thomas G. Hinton, ${ }^{\dagger}$ Daniel Coughlin ${ }^{\ddagger}$, G. Timothy Jannik ${ }^{* *}$ and \\ Eduardo B. Farfán ${ }^{* *}$ \\ * Chernobyl Center for Nuclear Safety, Radioactive Waste and Radioecology, International \\ Radioecology Laboratory, 07100, Slavutych, Ukraine \\ ${ }^{\dagger}$ Institute for Radioprotection and Nuclear Safety (IRSN), Cadarache; Bât. 186 - BP 3 - 13115 \\ Saint-Paul-Lez-Durance, France \\ *University of Georgia’s Savannah River Ecology Laboratory, Aiken, SC 29831, USA \\ $\S$ Sellafield Ltd, Seascale, Cumbria CA20 1PG, United Kingdom \\ Savannah River National Laboratory, Aiken, SC 29808, USA
}

\section{For reprints and correspondence contact:}

Eduardo B. Farfán, Ph.D.

Environmental Science and Biotechnology

Environmental Analysis Section

Savannah River National Laboratory

Savannah River Nuclear Solutions, LLC

773-42A, Room 236

Aiken, SC 29808

E-mail: Eduardo.Farfan@srnl.doe.gov

Phone: (803) 725-2257, Fax: (803) 725-7673

\section{Part of the Savannah River National Laboratory HPJ Special Issue}

October 2011 


\begin{abstract}
Radiation exposure of the biota in the shoreline area of the Chernobyl Nuclear Power Plant Cooling Pond was assessed to evaluate radiological consequences from the decommissioning of the Cooling Pond. The article addresses studies of radioactive contamination of the terrestrial faunal complex and radionuclide concentration ratios in bodies of small birds, small mammals, amphibians, and reptiles living in the area. The data were used to calculate doses to biota using the ERICA Tool software. Doses from ${ }^{90} \mathrm{Sr}$ and ${ }^{137} \mathrm{Cs}$ were calculated using the default parameters of the ERICA Tool and were shown to be consistent with biota doses calculated from the field data. However, the ERICA dose calculations for plutonium isotopes were much higher (2-5 times for small mammals and 10-14 times for birds) than the doses calculated using the experimental data. Currently, the total doses for the terrestrial biota do not exceed maximum recommended levels. However, if the Cooling Pond is allowed to drawdown naturally and the contaminants of the bottom sediments are exposed and enter the biological cycle, the calculated doses to biota may exceed the maximum recommended values. The study is important in establishing the current exposure conditions such that a baseline exists from which changes can be documented following the lowering of the reservoir water. Additionally, the study provided useful radioecological data on biota concentration ratios for some species that are poorly represented in the literature.
\end{abstract}

Key words: Chernobyl, decommissioning, risk assessment, radiobiology. 


\section{INTRODUCTION}

The Chernobyl Nuclear Power Plant (ChNPP) Cooling Pond is a man made basin that was created to dissipate heat from the ChNPP reactors near Pripyat, Ukraine. The pond is of considerable size, with a water surface area of over $22 \mathrm{~km}^{2}$, a volume of about $151,000,000 \mathrm{~m}^{3}$, and a mean depth of $6.6 \mathrm{~m}$. The water elevation is 5-7 $\mathrm{m}$ above the surface of the Pripyat River and it is recharged by the pumping of water from the river. The Cooling Pond became significantly contaminated by the accident that occurred at the ChNPP reactor Unit 4 in 1986. Unit 3 was the last ChNPP operational reactor that was supported by the Cooling Pond until it discontinued operations in December of 2000. The Cooling Pond, similar to all other ChNPP facilities, is now subject to decommissioning. The maintenance of the water elevation within the Cooling Pond requires continual recharging from the Pripyat River, and the costs of pumping water must be considered within the long term economic commitments. However, allowing large areas of the basin to naturally drawdown (via seepage and evaporation) would necessarily change the ecology of the region, with particular consequences related to the exposure of the residual radioactive contaminants associated with the sediments.

In the years 1999-2005, scientists performed a large number of studies (Weiss et al. 2000; Buckley et al. 2002): identifying characteristics of the Cooling Pond, evaluating various strategies of its decommissioning, and assessing the potential consequences of strategy implementation. Of primary concern was the resuspension and wind transport of contaminated particles. There was also expected hydrologic consequences as changes in ground water levels would impact directions of sub-surface water flows. 
The earlier assessments of the radiological consequences focused on assuring radiation safety for humans and the predictions appeared to be fairly optimistic (Buckley et al. 2002). Specifically, the resuspension of the exposed sediments due to wind was shown not to significantly increase contamination to the adjacent areas, and radiological doses for the people who work in those areas were not significantly increased. It was also projected that subsurface groundwater radionuclide transport to the Pripyat River would decrease and the radiological condition of the radioactive waste interim storage facility in the ChNPP immediate area would improve. In view of this, an approach was recommended to stop recharging the Cooling Pond with water, thus allowing it to naturally drawdown.

However, the theoretical assessment of radiological consequences regarding radiation safety of humans does not appear to be entirely consistent with the actual situation. The Chernobyl Exclusion Zone (ChEZ) is a secure administrative area with no "permanent residents", making it difficult to apply radiation safety criteria for humans to a full extent. Instead, it appears reasonable to apply an ecocentric approach and use radiation exposures of the fauna and flora of the Cooling Pond and its shoreline area as points for assessing consequences from the planned drawdown.

During the last decade, public views on radiation protection of biota significantly changed. The Rio Declaration of 1992 reflected a United Nations agreement that active measures are required to assure a sustainable development of the environment (United Nations 1992). The International Commission on Radiological Protection (ICRP) formed a special biota protection committee and issued a number of recommendations. Publication 91 (ICRP 2003) states that the approach to radiation protection of non-human species identified in Publication 26 (ICRP 1977, § 14) and confirmed in Publication 60 (ICRP 1991, §16) will have to be revised. Publication 103 (ICRP 2007, § 16) states the following: "The Commission continues to believe that this is likely 
to be the case in general terms under planned exposure situations, and that the human habitat has therefore been afforded a fairly high degree of protection. There are, however, other environments to consider, where the Commission's Recommendations for protection of humans have not been used or where humans are absent, and other exposure situations will arise where environmental consequences may need to be taken into account. The Commission is also aware of the needs of some national authorities to demonstrate directly and explicitly, that the environment is being protected even under planned exposure situations. Therefore, the Commission believes that a well-defined and scientifically substantiated structure is required to evaluate relationships between radiation and dose, between dose and result, and consequences of these results for non-human species."

Section 8 of this Publication (ICRP 2009) addresses major principles that the ICRP considers necessary to apply for assuring radiation protection of the biota. In Publication 108 (ICRP 2009), the ICRP proposes the environmental protection system be based on the following guidelines:

- $\quad$ use a small and specially selected set of reference fauna and flora;

- $\quad$ identify a set of certain dose models;

- identify a set of data for assessing radiation effects and dose-effects ratios for selected fauna and flora species that (together with other associated biological data) can be used for decision making for various circumstances, such as monitoring of practices and cases of interference.

Thus, now there are some necessary preconditions for assessments of risk to biota Additionally, several software packages have been developed to help assessors evaluate biota 
exposures,, for example, R\&D128/SP1a (Copplestone 2001), RESRAD-BIOTA (US DOE, 2004), and the ERICA Tool (Brown et al. 2008).

Effects of radiation on the shoreline biota of the ChNPP Cooling Pond have not been evaluated, either for the current conditions or for the situation when the highly contaminated bottom sediments become exposed. However, an inevitable increase of physical and biological availability of radioactive slurries, as well as a potential attractiveness of the former lakebed (since it will be covered with vegetation) will likely increase contamination of the biota. Analyses (Kashparov et al. 1999; Bulgakov et al. 2009) show that, during a fairly short time after the Cooling Pond's drawndown, the solubility (potential bioavailability) of radionuclides located in the bottom solutions will more than double. A similar drawdown of the water level in a contaminated reservoir at the U.S. DOE Savannah River Site in 1991-1994 resulted in a significant increase of contamination in birds, mammals, and vegetation (Whicker et al. 1997; Kennamer et al. 1998; Hinton et al. 1999). A similar effect was identified when another process water reservoir evaporated in the 1950's (Willard 1960). Changes in the terrain are known to cause changes in the trophic attractiveness of the region, e.g. smaller water reservoirs are more attractive for birds (Brisbin 1991) which may increase radioactive intake in their communities.

The study reported herein documents the concentrations and estimated dose to biota inhabiting the shoreline area of the ChNPP Cooling Pond. The study is important in establishing the current exposure conditions such that a baseline exists from which changes can be documented following the lowering of the reservoir water. Additionally, the study provided useful radioecological data on biota concentration ratios for some species that are poorly represented in the literature. 


\section{MATERIALS AND METHODS}

In 2007-2008, the International Radioecological Laboratory (IRL), Slavutich, Ukraine, with support of the Civil Research and Development Fund (UKB1-2884-KV-07) and Savannah River National Laboratory (Aiken, SC, USA), performed a preliminary radioecological study of the shoreline terrestrial systems of the ChNPP Cooling Pond (Gashchak et al, 2009c).

The IRL selected three $200 \mathrm{~m} \times 200 \mathrm{~m}$ experimental sites on the shores of the Cooling Pond (Fig. 1), The choice of sites was based on (1) the need to more fully define the existing radioecological situation, (2) radioanalytical capabilities, and (3) existing knowledge of the land forms and levels of contamination of the sediments . After the natural drawdown of the Cooling Pond, these experimental sites are expected to reasonably reflect changes occurring in the radiation and overall environmental situation of the region, including biota related changes. Each site included a segment of the shoreline of the Cooling Pond, the man-made levee that embanked the Cooling Pond, and some remaining elements of the former terrain. These sites will be in an immediate proximity to the exposed sediments of the Cooling Pond after it is drawn down.

Site \#1 is $800 \mathrm{~m}$ away from the mouth of the drainage canal. The bottom deposits near this site contain over 3.7-7.4 MBq m ${ }^{-2}$ of ${ }^{90} \mathrm{Sr}$ and ${ }^{137} \mathrm{Cs}$ (Weiss et al. 2000). Site \#2 is located in the northern shore of the Cooling Pond with a radionuclide inventory in the bottom deposits of about $0.4-0.8 \mathrm{MBq} \mathrm{m}{ }^{-2}$ of ${ }^{90} \mathrm{Sr}$ and $1.85 \mathrm{MBq} \mathrm{m}^{-2}$ of ${ }^{137} \mathrm{Cs}$ (Buckley et al. 2002). Site \#3 is located on the eastern shore, in a narrow $250 \mathrm{~m}$ levee between the Cooling Pond and the Pripyat River, with a radionuclide inventory of $0.2-0.4 \mathrm{MBq} \mathrm{m}^{-2}$ of ${ }^{90} \mathrm{Sr}$ and $1.4-1.9 \mathrm{MBq} \mathrm{m}{ }^{-2}$ of ${ }^{137} \mathrm{Cs}$ (Buckley et al. 2002). A more detailed description of soil, vegetation, and terrain conditions at these experimental sites can be found in Gashchak et al. (2009c). 
At each site, the equivalent dose rate $\left(\mathrm{EDR}, \mu \mathrm{Sv} \mathrm{h}^{-1}\right)$ was measured at points located in a $20 \mathrm{~m} \times 20 \mathrm{~m}$ grid, $1 \mathrm{~m}$ above the surface using a DBG-06T - dosimeter (photon radiation 0.05 3.0 $\mathrm{MeV}$; EDR range $0.10 \div 99.99 \mu \mathrm{Sv} \mathrm{h}^{-1}$ ). At 12 points, including three on the shoreline, three $20 \mathrm{~m}$ away from the shoreline, three $40-60 \mathrm{~m}$ away from the shoreline, and three 100-120 $\mathrm{m}$ away from the shoreline, soil samples were collected from depths of $0-20 \mathrm{~cm}$ using a cylindrical soil sampler (70 $\mathrm{mm}$ diameter). The entire $0-20 \mathrm{~cm}$ soil or sediment core was used for the analysis without division by layers. In the locations of the soil samples, vegetation was also sampled, i.e. vegetative parts of plants (leaves and green shoots). The grasses were sampled $5 \mathrm{~cm}$ above the soil surface. Prior to measurements, all samples were dried, sieved and thoroughly homogenized; the vegetation samples were not rinsed. The ${ }^{90} \mathrm{Sr}$ content was measured using a beta-spectrometer with a thin-filmed scintillation detector and a special IRL-developed measurement methodology (Bondarkov et al. 2002). The ${ }^{137} \mathrm{Cs}$ content was measured using a Canberra-Packard gamma-spectrometer with an HPGe detector. This work was performed in the summer of 2008.

In 2007-2008, small vertebrate species (mammals, birds, amphibians, and reptiles) were captured in the experimental areas to evaluate live, whole-body animal ${ }^{90} \mathrm{Sr}$ and ${ }^{137} \mathrm{Cs}$ contents (after the measurements the animals were released). A mobile spectrometric system was used that included the following six components: (1) a box container $(100 \times 300 \times 100 \mathrm{~mm})$ for animals with 100-150 mm lead shielding; (2) a beta-detector (scintillation plastic thin-filmed $0.1 \mathrm{~mm}, 60$ $\mathrm{mm}$ in diameter) installed vertically $11 \mathrm{~cm}$ above the animal container; (3) a Canberra gammaspectrometer with a $\mathrm{NaI}$ scintillation detector (Tl-activated, $63 \mathrm{~mm}$ in diameter) installed horizontally towards the animal container (the energy resolution of the detector was $50.1 \mathrm{keV}$ for $661 \mathrm{keV}$, gamma rays and the spectrum was collected in 1,024 channels); (4) an ASA100 
analyzer for processing beta-spectrum with an associated software package «Beta + » (the Institute of Nuclear Research, Kiev, Ukraine); (5) an InSpector multi-channel analyzer with GENIE-2000 software package (Canberra Packard) for gamma-spectrum processing; and (6) a personal computer. The spectroscopy system was installed in a mobile van and equipped with an uninterruptable power supply from a gasoline generator.

This method made it possible to simultaneously measure ${ }^{90} \mathrm{Sr}$ and ${ }^{137} \mathrm{Cs}$ in the whole-body of an animal. When the total ${ }^{90} \mathrm{Sr}$ content was measured using the beta-spectrometer, it was taken into account that the measured object was "thick-layered" and that it contained comparable ${ }^{137} \mathrm{Cs}$ content (Bondarkov et al. 2002) which was characteristic of the ChEZ. With the excess of ${ }^{137} \mathrm{Cs}$ gamma-quanta ( $\left.{ }^{137 \mathrm{~m}} \mathrm{Ba}-661 \mathrm{keV}\right)$, the effectiveness of the recording by the detector was $1-2$ orders of magnitude lower than for the ${ }^{90} \mathrm{Sr}$ beta-particles, which made it possible to fairly accurately estimate the ${ }^{90} \mathrm{Sr}$ content, even with ${ }^{90} \mathrm{Sr}$ to ${ }^{137} \mathrm{Cs}$ ratios in the range of 1 to 30 . The experimental spectra were correlated with the measured spectra from calibrated sources containing known quantities of ${ }^{90} \mathrm{Sr}+{ }^{90} \mathrm{Y}$ and ${ }^{137} \mathrm{Cs}$ (six phantoms from $6 \mathrm{~g}$ to $20 \mathrm{~g}$ and linear sizes close to that of the animals) and the current background. To make sure that the measurements were adequate, all equipment was calibrated daily.

During measurements, the animal was placed into a disposable cardboard container (of one of three dimensions, depending on the animal body size, i.e. $40 \times 35 \times 70,50 \times 35 \times 100,60$ $\times 50 \times 170 \mathrm{~mm}$ ), with the upper side of the container possessing a $0.1 \mathrm{~mm}$ thick plastic. The measurement operation was as gentle as possible to reduce stress for the animals, and all animals were released alive.

The measurements lasted from 150 to 3,200 seconds, depending on the level of contamination. The background of both spectrometers ranged from 0.2 to $0.8 \mathrm{cps}$. The value of 
the minimally detectable activity (MDA) ranged from 7 to $155 \mathrm{~Bq}$ (it was slightly lower for ${ }^{90} \mathrm{Sr}$ than for ${ }^{137} \mathrm{Cs}$ ), depending on: the external radiation conditions, contamination of the measured animal and duration of the measurements. The error associated with the ${ }^{90} \mathrm{Sr}$ and ${ }^{137} \mathrm{Cs}$ measurements usually did not exceed $20-30 \%$. If the error exceeded $70 \%$, the EDR measurement value was divided by two for use in the analysis. Earlier studies showed that, in most cases, the ${ }^{90} \mathrm{Sr}$ measurements results using this method differed from the radiochemical analysis method by no more than 20\% (Bondarkov et al. 2002).

The plutonium $\left({ }^{238} \mathrm{Pu},{ }^{239,240} \mathrm{Pu}\right)$ content was measured in a limited number of soil and bottom sediment samples. A standard radiochemical method was used for the measurements. The ashed samples were diluted in $65 \% \mathrm{HNO}_{3}$ and a tracer $\left({ }^{242} \mathrm{Pu}\right)$ was added to assess the chemical yield. After plutonium was separated with an ion exchange resin (Bio Rad AG 1X8, 100-200 mesh), the associated isotopes and their salts were precipitated on a flat target. The ${ }^{238} \mathrm{Pu}$ and ${ }^{239,240} \mathrm{Pu}$ content was measured by alpha-spectroscopy with a PIPS detector.

The bioavailability of the radionuclides at the experimental sites was assessed by calculating the concentration ratio $(C R)$ in the ecosystem-to-biota chain, specifically as a ratio of the radionuclide concentration in the animal (fresh weight) or plant (dry weight) $\left(A_{b}\right)$ to the average geometric mean concentration $\left(A_{s}\right)$ in the soil (dry weight).

The ERICA Assessment Tool, Version 1.0, May 2009 (http://www.project.facilia.se/erica/index.html) was utilized to assess the dose from different environmental sources of radiation. This software application has a multi-tiered structure of assessment supported by a detailed help function. The software contains the User's Manual and the database on radionuclide transfer coefficients and adjustment factors to calculate dose rates (Beresford et al. 2007). 
The following were considered guidance doses for biota, below which significant damage to the population is thought to be unlikely: $40 \mu \mathrm{Gy} \mathrm{h}^{-1}\left(1 \mathrm{mGy} \mathrm{d}^{-1}\right)$ for terrestrial animals and 400 $\mu \mathrm{Gy} \mathrm{h}^{-1}\left(10 \mathrm{mGy} \mathrm{d}^{-1}\right)$ for terrestrial plants. These values were recommended by the IAEA (1992), UNSCEAR (1996), and the ICRP (2009). They have been adopted by the US Department of Energy (DOE-STD-1153 2002). Three options were used for calculating the dose rate.

Option 1. Reference organisms (bird, rat, amphibians, reptiles, and grass) provided by the software as default were used for the calculations. The radionuclide $\mathrm{CR}$ and dose factors proposed by the software were applied. The calculations were performed relative to the average concentration of radionuclides in the soil $\left(A_{s}\right)$ of Site $\# 1$, the most contaminated area (conservative assessment). Calculations were performed for the following isotopes: ${ }^{90} \mathrm{Sr},{ }^{137} \mathrm{Cs}$, ${ }^{238} \mathrm{Pu}$, and ${ }^{239+240} \mathrm{Pu}$. The ERICA software has a separate entry for ${ }^{239} \mathrm{Pu}$ and ${ }^{240} \mathrm{Pu}$, but the total ${ }^{239+240} \mathrm{Pu}$ amount was measured during the study. In order to create a conservative value, the total ${ }^{239+240} \mathrm{Pu}$ value was entered as ${ }^{240} \mathrm{Pu}$ because its dose conversion coefficient (DCC) is higher.

Option 2. Additional bird and animal species that are common in the fauna complex of the Cooling Pond shoreline area were added to the list of reference species provided by the ERICA software. These included: small passerine birds (Erithacus rubecula, Fringilla coelebs, Parus major); song thrushes (Turdus philomelos); common shrews (Sorex araneus); and small rodents (Apodemus agrarius, Myodes glareolus, Sylvaemus flavicollis). Their body geometry is known to correspond to an ellipsoid with the following characteristics: small passerine birds -3.0 $\times 3.0 \times 5.0 \mathrm{~cm}$, thrushes $-8.0 \times 8.0 \times 15.0 \mathrm{~cm}$; common shrews $-1.5 \times 1.5 \times 7.0 \mathrm{~cm}$; and small rodents $-2.5 \times 2.5 \times 9.0 \mathrm{~cm}$. The ${ }^{90} \mathrm{Sr}$ and ${ }^{137} \mathrm{Cs} \mathrm{CR}\left(C R=A_{b} / A_{s}\right)$ were based on either current measurement results or earlier measurements performed by IRL for similar groups of species inhabiting the ChEZ (Table 1; Maklyuk et al. 2008; Gashchak et al. 2009a; Gashchak et al. 2009b; Barnett et al. 2009). For ${ }^{241} \mathrm{Am}$, the concentration ratio proposed in the ERICA database 
was used. The biota doses were calculated for the conditions of Site \#1, the most contaminated of the three experimental sites.

Option 3. Calculations were conducted to estimate the doses that species in areas of the exposed bottom sediments may potentially receive. The concentration of radionuclides in the exposed sediments was assumed to be equal to the earlier estimated contamination of the Cooling Pond bottom deposits (Table 2; Weiss et al. 2000; Buckley et al. 2002). Calculations were performed for both reference animal and plants species proposed by the software by default and for some actual species typical for the region. The parameters of calculations for the actual species were the same as in Option 2. The reference organisms provided by the ERICA software by default were used for the calculations. As in the previous calculations, the ${ }^{239+240} \mathrm{Pu}$ specific activity was entered as ${ }^{240} \mathrm{Pu}$ specific activity.

In addition, it was taken into account that other radionuclides would also contribute to the contamination of the bottom sediments, such as ${ }^{241} \mathrm{Am}$ and ${ }^{241} \mathrm{Pu}$ (Weiss et al. 2000; Buckley et al. 2002); ${ }^{241} \mathrm{Am}$ tends to accumulate as a product of ${ }^{241} \mathrm{Pu}$ decay. Their content in the components of the Cooling Pond shoreline ecosystem was not measured. However, since physical characteristics of ${ }^{241} \mathrm{Am}$ radiation and its bioavailability make it more radiologically significant than plutonium isotopes, it was decided to include ${ }^{241} \mathrm{Am}$ in the calculations of the potential doses to biota. The doses for ${ }^{241} \mathrm{Pu}$ were also calculated. The same concentration ratio was used for all plutonium isotopes and the default values provided by the ERICA software for ${ }^{241}$ Am was used. 


\section{RESULTS AND DISCUSSION}

\section{Results of the radioecological survey of the experimental sites}

The radioecological survey showed that contamination at each experimental site was unevenly distributed (Table 3 ). The ${ }^{137} \mathrm{Cs}$ and ${ }^{90} \mathrm{Sr}$ soil concentrations $\left(A_{s}\right)$ ranged within $1-3$ orders of magnitude for each experimental site (Table 4). Although the highest dose rate was measured at Site \#2, followed in decreasing order by Site \#1 and Site \#3 (Table 3), the sites formed a different sequence regarding the radionuclide concentration, specifically: Site \#1 > Site $\# 2>$ Site \#3.

The ${ }^{90} \mathrm{Sr}$ and ${ }^{137} \mathrm{Cs}$ biota concentration values $\left(A_{b}\right)$ for the various biota measured are provided in Tables 5-8. The large variations of the ${ }^{90} \mathrm{Sr}$ and ${ }^{137} \mathrm{Cs}$ activity concentrations for the plants and animals are similar to those shown for the soil values. For example, the ${ }^{90} \mathrm{Sr} A_{b}$ value ranges over four orders of magnitude, even within an experimental site. However, differences in activity concentrations between groups of species are consistent: the lowest ${ }^{90} \mathrm{Sr}$ values were found in bodies of birds, the next were mice, and the highest values were found in herbaceous plants [Two-Sample T-Test for means $A_{b}{ }^{90} \mathrm{Sr}$ birds $\neq$ mice, $\mathrm{P}$ value $\left.=0.018(\alpha=0.05)\right]$. The range of variations in the average ${ }^{137} \mathrm{Cs} A_{b}$ values is not as pronounced. Similar to the ${ }^{90} \mathrm{Sr}$ results, the lowest average ${ }^{137} \mathrm{Cs} A_{b}$ values were typically found in birds; however, the highest ${ }^{137} \mathrm{Cs} A_{b}$ values were in small mammals inhabiting the same area [Two-sample T-Test for means $A_{b}{ }^{137} \mathrm{Cs}$ birds $\neq$ mice $\mathrm{P}$ value $=7.4 \times 10-5(\alpha=0.05)]$.

The ${ }^{137} \mathrm{Cs} /{ }^{90} \mathrm{Sr}$ ratio measured in the soil was on average 1.8 (range $0.3-25.3$ ). This corresponds to their ratio in the soil within the ChNPP $10 \mathrm{~km}$ "proximity" zone (Kashparov 2001) and their ratio (1.16) in the fuel of ChNPP Reactor \#4 (Pazukhin 1999). The highest values 
were measured in the soils of the experimental sites (Fig. 2) while, in most cases, the ${ }^{137} \mathrm{Cs} /{ }^{90} \mathrm{Sr}$ ratio in the biota was less than 1.0.

The ${ }^{90} \mathrm{Sr}$ and ${ }^{137} \mathrm{Cs} C R$ clearly demonstrates that the ${ }^{90} \mathrm{Sr}$ intake into the biota noticeably exceeds the ${ }^{137} \mathrm{Cs}$ intake (Fig. 3). For terrestrial plants, the average difference reaches $1-2$ orders of magnitude while for animals this difference is only a few factors (Table 9). In general, the ${ }^{90} \mathrm{Sr}$ CR for the terrestrial plants exceeds the similar value for the animals by a factor of few tens while the differences in the ${ }^{137} \mathrm{Cs} \mathrm{CR}$ in the biota appear insignificant.

Currently, there are only preliminary data on the ${ }^{239,240} \mathrm{Pu}$ and ${ }^{238} \mathrm{Pu}$ content in the soil and biota of the terrestrial ecosystems (Table 10). The plutonium $A_{b}$ values in the biota are a hundred times lower than in the soil. The calculated CR values for these isotopes were as follows: ${ }^{239,240} \mathrm{Pu}$ -0.023 for the herbaceous plants (range of $0.006-0.218$ ), ${ }^{238} \mathrm{Pu}-0.023$ (range of $0.006-0.256$ ). Overall, there was a higher observed plutonium bioavailability at Site \#2, while there were practically no differences regarding this value at the other sites.

\section{Results of dose assessments}

Option 1. Dose calculations were made using the ERICA Tool default parameters for conventional reference species that could have inhabited Site \#1. Default parameters demonstrate potentially high values for reptiles and small mammals (Table 11). The high values for reptiles may be due to a high accumulation of ${ }^{90} \mathrm{Sr}$, as a result of using a relatively high $\mathrm{CR}$ value defaulted within the ERICA Tool. Default CRs also resulted in rats having a high dose rate from ${ }^{137}$ Cs and a correspondingly high risk assessment value under the conservative scenario. For other species, dose rates are significantly lower than the reference doses (i.e. $40 \mu \mathrm{Gy} \mathrm{h}^{-1}$ for animals and $400 \mu \mathrm{Gy} \mathrm{h}^{-1}$ for plants). A major contribution to the total dose is associated with internal 
exposure by incorporated ${ }^{90} \mathrm{Sr}$ and ${ }^{137} \mathrm{Cs}$. Plutonium isotopes contributed less than $2.5 \%$ of the total doses to biota.

Option 2. The doses that the reference and actual biota representatives might receive under the conditions of Site \#1, based on the ratios obtained during the radiological surveys, are shown in Tables 12-13. According to these calculations, external irradiation of the species is primarily due to ${ }^{137} \mathrm{Cs}$ in the environment and the contribution from the other isotopes is negligibly small (Table 12). The internal dose of the biota is primarily due to the accumulated ${ }^{90} \mathrm{Sr}$, while the ${ }^{137} \mathrm{Cs}$ contribution to internal dose is several factors lower (Table 13). The contribution of the incorporated plutonium isotopes is negligibly small.

Dose assessments obtained for Option 1 (Table 11) were consistent with the dose assessments based on the experimental data (Option 2, Table 14). For example, ${ }^{90} \mathrm{Sr}$ associated doses for amphibians were $3.16 \mu \mathrm{Gy} \mathrm{h}^{-1}$ (Option 1) and $4.91 \mu \mathrm{Gy} \mathrm{h}^{-1}$ (Option 2); ${ }^{137} \mathrm{Cs}$ associated doses for amphibians were comparable at 2.72 (Option 1) and $1.92 \mu \mathrm{Gy} \mathrm{h}^{-1}$; birds -3.61 and 1.6 $\mu \mathrm{Gy} \mathrm{h} \mathrm{h}^{-1}$, respectively; and for rats -9.78 and $5.39 \mu \mathrm{Gy} \mathrm{h}^{-1}$, Option 1 and Option 2 , respectively. The herbaceous plants are an exception because their ${ }^{90} \mathrm{Sr}$ dose assessment, based on the experimental data, was 46 times higher than that estimated by the ERICA Tool. The plutonium isotope doses, based on the experimental data, were significantly lower than those obtained by the ERICA Tool. Specifically, they were $3-5$ times lower for the amphibians, $14-16$ times lower for birds, and 2.5 - 5 times lower for small mammals.

In all cases, dose rate estimates for reptiles based on the experimental data (Table 14) were significantly lower than the estimates proposed by the ERICA Tool: a factor of 100 for plutonium isotopes, a factor of 20 for ${ }^{90} \mathrm{Sr}$, and a factor of 5 for ${ }^{137} \mathrm{Cs}$.

In general, both calculation options show that the existing dose rates for terrestrial representatives of the Cooling Pond biota do not exceed recommended allowable doses (Table 
15). Use of the ERICA Tool for the assessment of radionuclide concentrations for various species provided good agreement with actual measurements data, with the exception of reptiles (Table $16)$.

Option 3. A satisfactory agreement between the dose rates calculated by two calculation methods (Option 1 and Option 2) made it possible to apply the ERICA Tool software for predicting doses and risks for biota species if they were to inhabit areas of the exposed contaminated sediments of the Cooling Pond. Using the calculation algorithm according to Option 3, the conservative dose rate estimates were computed for external (Table 17) and internal (Table 18) exposure pathways.

According to these estimates, dose rates to biota living on the exposed sediments of the drawndown Cooling Pond may reach fairly large values that exceed the maximum recommended values (i.e all the risk factors exceed a value of one; Table 19). ${ }^{90} \mathrm{Sr}$ incorporated in the body provides the major contribution to the total dose (up to $41-67 \%$ for animals and up to $93 \%$ for herbaceous plants). The ${ }^{137} \mathrm{Cs}$ presence in the ecosystem will primarily affect the external exposure: up to $29-54 \%$ of the total dose for animals and about $7 \%$ of the total dose for plants. The contribution of transuranic isotopes existing in the environment and incorporated in bodies of animals does not exceed $2.1-5.7 \%$ for animals and $0.2 \%$ for plants. As a consequence, risk factors significantly exceed 1, reaching 2.7-4 for amphibians and small mammals (Table 19).

In a more favorable scenario based on the average estimates, the highest risks are estimated to be to small mammals (Table 20), and those risks are close to the maximum recommended for biota (i.e. risk factors $\sim 1$ ).

Therefore, the radiological consequences to terrestrial biota that might inhabit the exposed sediments following a drawdown of the Cooling Pond are considered acceptable if the most probable doses are applied and current risk factors of 40 and $400 \mathrm{uGy} \mathrm{h}{ }^{-1}$ are used. However, 
more conservative estimates indicate a significant exceedance of the risk to biota. Both estimates were performed with the assumption that the exposed radionuclides in the bottom sediments will have the same bioavailability as the current radionuclides in the remaining terrestrial part of the ChEZ. However, this assumption may not be correct. As previously stated, evaporation of water reservoirs results in a significant increase of not only physical accessibility of the radioactive materials accumulated in the bottom sediments, but also bioavailability in the substrate-to-plants system (Kashparov et al. 1999; Bulgakov et al. 2009). Therefore, risk assessments to biota based on average values may be underestimated. Thus, risks for the terrestrial biota that will inhabit the most contaminated areas of the Cooling Pond are likely to exceed recommended values.

\section{CONCLUSION}

Assessments of the radiological consequences from drawing down the water level of the ChNPP Cooling Pond indicate that risks to humans do not appreciable increase (Buckley et al. 2002). These findings are partially due to the lack of a resident human population and inappropriateness of typical human risk assessment scenarios. The risks to non-human biota using radionuclide concentration data collected for species currently living adjacent to the Cooling Pond was assessed. Estimates of the future exposure to biota were also made based on activity concentrations of the sediments that will be uncovered following drawdown of the Cooling Pond water. Enhanced exposures to contaminated sediments will likely cause risk factors to exceed one for non-human biota inhabiting the Pond's shoreline. A risk factor greater than one indicates that dose to biota exceeds levels considered safe. Additionally, within a tiered modeling approach, scenarios with risk factors greater than one should not be screened out, but indicate that additional, more site specific calculations are required to determine effects. The increased risk to 
biota is partially due to external exposure to ${ }^{137} \mathrm{Cs}$, but to a greater extent, to incorporation of ${ }^{90} \mathrm{Sr}$ within the food web. However, because these assessments were based on available data that only partially describes radioactive contamination of the shoreline ecosystem; and because bioavailability of the radioisotopes within the sediments are predicted to increase following the Cooling Pond drawdown, we anticipate that the risks to biota have not yet been adequately examined.

Acknowledgments - The authors would like to thank Ines Triay, Yvette Collazo, Kurt Gerdes, and Ana Han for their support of the U.S. Department of Energy Office of Environmental Management's International Cooperative Program with IRL. The authors would also like to express their gratitude to Tatyana Albert (Thomas E. Albert and Associates, Inc.) for translating documents and reports prepared at SRNL and IRL.

Disclaimer - This manuscript has been co-authored by Savannah River Nuclear Solutions, LLC under Contract No. DE-AC09-08SR22470 with the U.S. Department of Energy. The United States Government retains and the publisher, by accepting this article for publication, acknowledges that the United States Government retains a non-exclusive, paid-up, irrevocable, worldwide license to publish or reproduce the published form of this work, or allow others to do so, for United States Government purposes. Mention of trade names or commercial products does not constitute endorsement or recommendation for use by the authors or their corresponding organizations. 


\section{REFERENCES}

Barnett CL, Gaschak S, Beresford NA, Howard BJ, Maksimenko AM. Radionuclide activity concentrations in two species of reptiles from the Chernobyl exclusion zone.

Radioprotection, 44: 537-542; 2009.

Beresford N, Brown J, Copplestone D, Garnier-Laplace J, Howard BJ, Larsson C-M, Oughton O, Prohl G, Zinger I. D-ERICA: An INTEGRATED APPROACH to the assessment and management of environmental risks from ionising radiation. Description of purpose, methodology and application. 2007. Available at:

https://wiki.ceh.ac.uk/display/rpemain/ERICA+reports Accessed 04 February 2011.

Bondarkov MD, Bondarkov DM, Zheltonozhsky VA, Maksimenko AM, Sadovnikov LV, Strilchuk NV. A method of ${ }^{90} \mathrm{Sr}$ concentration measurement in biological objects and soil samples without radiochemistry. Nucl Phys At Energy 2:162-167; 2002.

Brisbin IL Jr. Avian radioecology. Curr Ornithol 8:69-140; 1991.

Brown JE, Alfonso B, Avila R, Beresford NA, Copplestone D, Prohl G, Ulanovsky A. The ERICA Tool. J Environ Radioact 99:1371-1383; 2008.

Buckley MJ, Bugai D, Dutton L M C D, Gerchikov MY, Kashparov VA, Ledenev A, Voitzehovich O, Weiss D, Zheleznyak M. Drawing up and evaluating remediation strategies for the Chernobyl Cooling Pond. In: Final Report. B7 5230/2000/306958/MAR/C2; 2002. 
Bulgakov A, Konoplev A, Smith J, Laptev G, Voitsekhovich O. Fuel particles in the Chernobyl cooling pond: current state and prediction for remediation options. J Environ Radioact 100:329-332; 2009.

D Copplestone, S Bielby, SR Jones, D Patton, P Daniel and, I Gize. Impact assessment of ionising radiation on wildlife. R \& D Publication 128 // ERC, University of Liverpool, Environment Agency, Bristol; 2001

Gashchak SP, Bondarkov MD, Maklyuk YA, Maksimenko AM, Martynenko VI, Chizhevsky IV. Stocks of ${ }^{90} \mathrm{Sr}$ and ${ }^{137} \mathrm{Cs}$ in biomass of birds in the territory of Chernobyl zone and size of radionuclide export with birds outside. Problems of the Chernobyl Exclusion Zone 9:87-101; 2009a.

Gashchak SP, Maklyuk YA, Maksimenko AM, Bondarkov MD. Radioecology of amphibians in Chernobyl zone. Problems of the Chernobyl Exclusion Zone 9:76-86; $2009 \mathrm{~b}$.

Gashchak SP, Oskolkov BY, Bondarkov MD, Maksimenko AM, Maksimenko VM, Martynenko VI, Hinton TG. Complex characteristics of terrestrial ecosystems on the bank of cooling pond of ChNPP on the eve of its drawdown. Problems of the Chernobyl Exclusion Zone 9: $57-75 ; 2009 \mathrm{c}$.

Hinton TG, Bell CM, Whicker FW, Phillippi T. Temporal changes and factors influencing ${ }^{137} \mathrm{Cs}$ concentration in vegetation colonizing an exposed lake bed over a three year period. $\mathrm{J}$ Environ Radioact 44:1-19; 1999.

International Atomic Energy Agency. Effects of ionizing radiation on plants and animals at levels implied by current radiation protection standards. Vienna: IAEA; Technical Reports Series No. 332.; 1992. 
International Commission on Radiological Protection. Recommendations the International Radiological of Commission Protection. Oxford: Pergamon Press; ICRP Publication 1; Ann ICRP 1(3); 1977.

International Commission on Radiological Protection. 1990 Recommendations of the International Radiological of Commission Protection. Oxford: Pergamon Press; ICRP Publication 60; Ann ICRP 21(1-3); 1991.

International Commission on Radiological Protection. A framework for assessing the impact of ionizing radiation on non-human species. Oxford: Pergamon Press; ICRP Publication 91; Ann ICRP 33 (3); 2003.

International Commission on Radiological Protection. The 2007 Recommendations of the International Commission on Radiological Protection. New York: Elsevier; ICRP Publication 103; Ann ICRP 37(2-4); 2007.

International Commission on Radiological Protection. Environmental protection: The Concept and use of reference animals and plants. New York: Elsevier; ICRP Publication 108; Ann ICRP 38 (4-6); 2009.

Kashparov VA, Oughton DH, Zvarich SI, Protsak VP, Levchuk SE. Kinetics of fuel particle weathering and ${ }^{90} \mathrm{Sr}$ mobility in the Chernobyl $30 \mathrm{~km}$ exclusion zone. Health Phys $76: 251-259 ; 1999$.

Kashparov VA. Forming and dynamic of radioactive contamination of environment during the accident of Chernobyl NPP and in post-accidental period. In: Collection of articles of National Academy of Science of Ukraine "Chernobyl. Exclusion zone”. Kiev, Naukova Dumka, 11-46; 2001. 
Kennamer RA, Brisbin IL, McCreedy CD, Burger J. Radiocesium in mourning doves: effects of a contaminated reservoir drawdown and risk to human consumers. J Wildl Manage $62: 497-508 ; 1998$

Maklyuk Y, Gashchak S, Maksimenko A, Bondarkov M, Beresford N. Dose rates to small mammals in the Chernobyl zone 19 years after the accident. Proceedings of the International conference on radioecology and environmental radioactivity. Bergen, Norway: Osteras; NRPA; 208-211; 2008.

Pazukhin E.M., 1999. Lava-like fuel containing masses of the ChNPP Reactor Unit \# 4. physical and chemical properties, scenario of formation, environmental impact. Post-Doctorate Thesis, Specialty \# 21.06.01. Chernobyl, manuscript, 1999.

Shestopalov VM. Atlas of Chernobyl exclusion zone. Ukrainian Academy of Science: Kiev: 1996.

United Nations. Convention on Biological Diversity. Rio de Janeiro: June 1992. Available at: http://www.cbd.int/convention/text. Accessed 04 February 2011.

United Nations Scientific Committee on the Effect of Atomic Radiation. Sources and effects of ionizing radiation. UNSCEAR Report of the United Nations Scientific Committee on the Effect of Atomic Radiation to the General Assembly, with Scientific Annex. Effects of radiation on the environment. United Nations. UNSCEAR. New York. 1996.

U.S. Department of Energy. A Graded approach for evaluating radiation doses to aquatic and terrestrial Biota. In: Technical Standard. DOE-STD-1153; 2002.

U.S. Department of Energy. RESRAD-BIOTA: A tool for implementing a graded approach to biota dose evaluations. ISCORS Technical Report 2004-02, Interagency Steering 
Committee on Radiation Standards. Springfield, U.S. Department of Commerce, Technology Administration, National Technical Information Service; 2004.

Weiss D, Larue J, Bogorinsky P, Watermeyer V, Voitsekhovich O, Sobotovich E, Bugai D, Oskolkov B. Collection and Analysis of Information and Data related to the Contamination of the Chernobyl Cooling Pond. In: Final Report. B75350/99/6241/MAR/C2; 2000.

Whicker FW, Hinton TG, Niquette DJ. Effects of a partial draw down on the dynamics of 137Cs in an abandoned reactor cooling reservoir. In: Studies in Environmental Science. Proceedings on an International Seminar on Freshwater and Estuarine Radioecology. 1997: 193-202.

Willard WK. Avian uptake of fission products from an area contaminated by low-level atomic wastes. Science 132:148-150; 1960.

Wood MD, Beresford NA, Barnett CL, Copplestone D, Leah RT. Assessing radiation impact at a protected coastal sand dune site: an intercomparison of models for estimating the radiological exposure of non-human biota. J Environ Radioact 100:1034-1052; 2009. 


\section{FIGURE CAPTIONS}

Fig. 1. Locations of the three experimental sites in the ChNPP cooling pond area. The ${ }^{137} \mathrm{Cs}$ deposition patterns (MBq km${ }^{-2}$ ) are taken from Shestopalov (1996).

Fig. 2. ${ }^{137} \mathrm{Cs}$ to ${ }^{90} \mathrm{Sr}$ ratio in biota of the ChNPP Cooling Pond shoreline ecosystem, (average \pm standard deviation of $\log (137 \mathrm{Cs} / 90 \mathrm{Sr}))$.

Fig. 3. ${ }^{90} \mathrm{Sr}$ and ${ }^{137} \mathrm{Cs}$ concentration ratios $\left(C R=A_{b} / A_{s}\right)$ for ChNPP cooling pond biota, (average \pm standard deviation $\log C R)$.

Fig. 4. Plutonium concentration ratios $\left(C R=A_{b} / A_{s}\right)$ in herbaceous plants of the ChNPP Cooling Pond shoreline ecosystems in 2007-2008, (average \pm standard deviation log CR). 


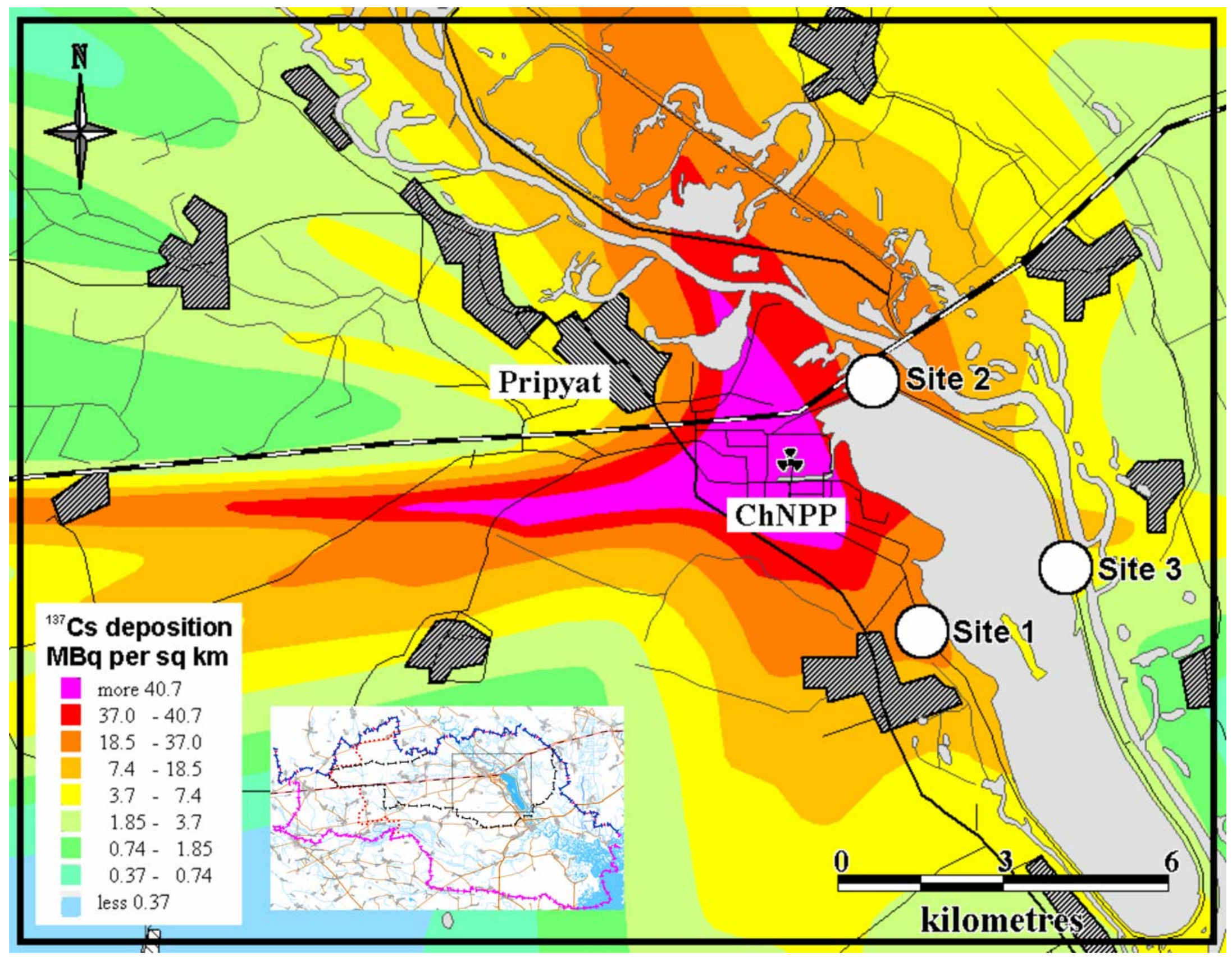

Fig. 1. Locations of the three experimental sites in the ChNPP cooling pond area. The ${ }^{137} \mathrm{Cs}$ deposition patterns $\left(\mathrm{MBq}_{\mathrm{km}}{ }^{-2}\right)$ are taken from Shestopalov (1996). 


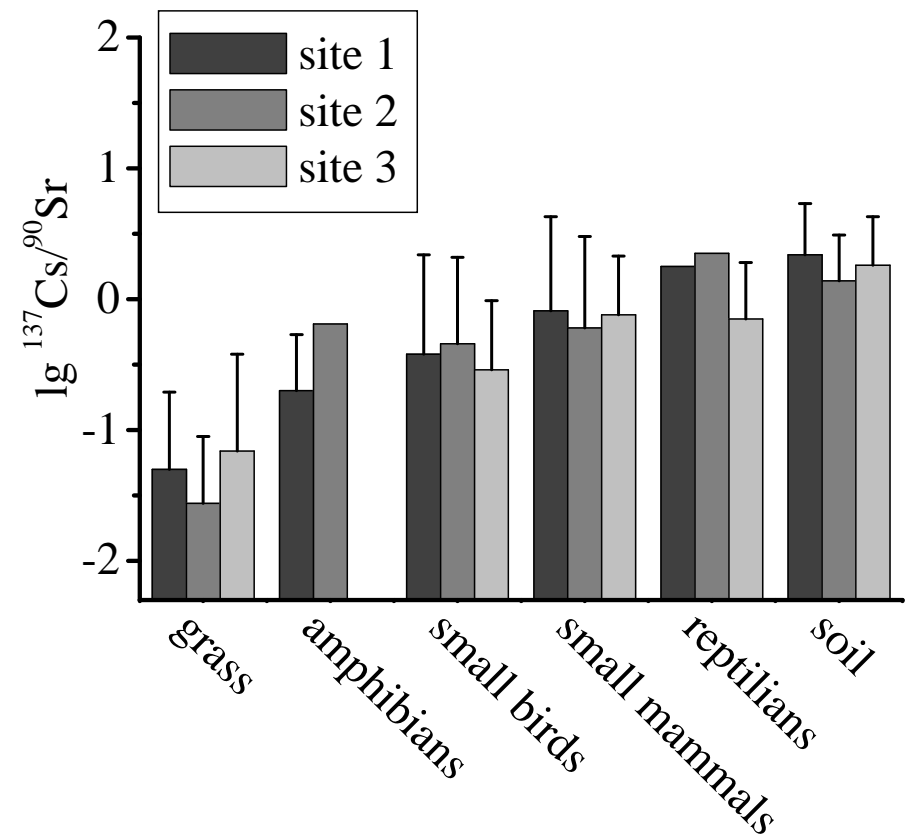

Fig. $2 .{ }^{137} \mathrm{Cs}$ to ${ }^{90} \mathrm{Sr}$ ratio in biota of the ChNPP Cooling Pond shoreline ecosystem, (average \pm standard deviation of $\log \left(\left(^{137} \mathrm{Cs} /{ }^{90} \mathrm{Sr}\right)\right.$ ). 


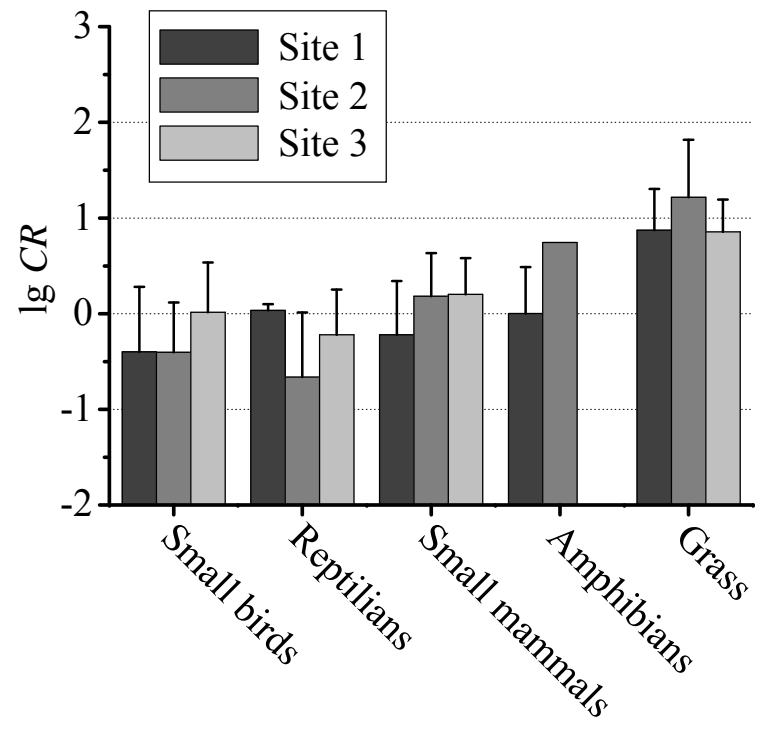

a) ${ }^{90} \mathrm{Sr}$

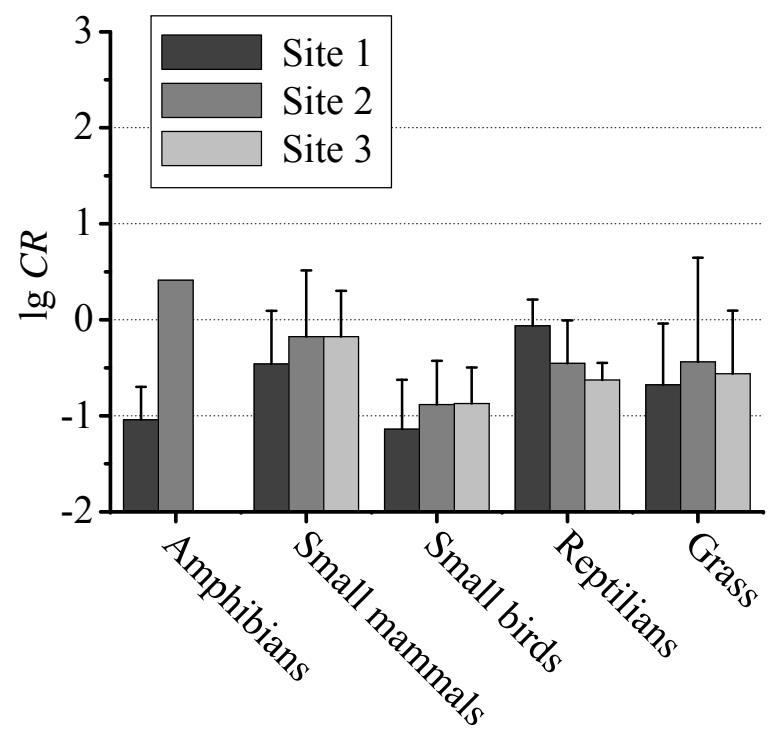

b) ${ }^{137} \mathrm{Cs}$

Fig. 3. ${ }^{90} \mathrm{Sr}$ and ${ }^{137} \mathrm{Cs}$ concentration ratios $\left(C R=A_{b} / A_{s}\right)$ for $\mathrm{ChNPP}$ cooling pond biota, (average \pm standard deviation $\log C R$ ). 


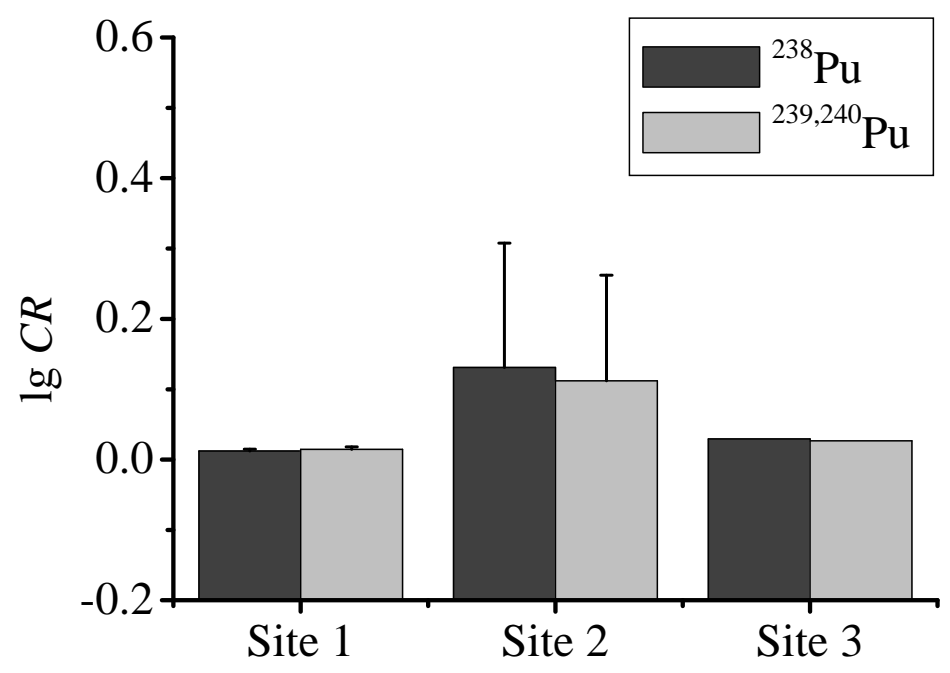

Fig. 4. Plutonium concentration ratios $\left(C R=A_{b} / A_{s}\right)$ in herbaceous plants of the ChNPP Cooling Pond shoreline ecosystems in 2007-2008, (average \pm standard deviation log $C R$ ). 
Table 1. Radionuclide concentration factors utilized for calculations of estimated doses, $\left(\mathrm{kBq} \mathrm{kg}^{-1}\right.$ per $\left.\mathrm{kBq} \mathrm{kg}^{-1}\right)$.

\begin{tabular}{lcccc}
\hline \multicolumn{1}{c}{ Species } & ${ }^{\mathbf{9 0}} \mathbf{S r}$ & ${ }^{\mathbf{1 3 7}} \mathbf{C s}$ & $\mathbf{P u}$ & ${ }^{{ }^{41} \mathbf{A m}}$ \\
\hline Grass* & 9.74 & 0.28 & 0.014 & 0.005 \\
Amphibians* & 1.28 & 0.18 & 0.009 & 0.041 \\
Reptilians* & 0.53 & 0.38 & 0.0003 & 0.041 \\
Birds (duck)* & 0.59 & 0.28 & 0.002 & 0.041 \\
Mammals (rat)* & 1.25 & 0.57 & 0.009 & 0.041 \\
Small passerine & 0.5 & 0.1 & 0.002 & 0.041 \\
birds & 0.5 & 0.1 & 0.002 & 0.041 \\
Song thrushes & 1.25 & 0.57 & 0.009 & 0.041 \\
Common shrews & 1.25 & 0.57 & 0.009 & 0.041 \\
Small rodents & & & & \\
\hline
\end{tabular}

* Asterisks indicate default reference species proposed by the ERICA software. 
Table 2. Concentration of radionuclides in the $0-2 \mathrm{~cm}$ layer of the exposed bottom of the ChNPP Cooling Pond at Experimental Site \# 1 (Buckley et al. 2002) utilized in the calculations of the potential dose exposures $(\mathrm{kBq} / \mathrm{kg})$.

\begin{tabular}{lcc}
\hline Radionuclide & Average Value & Maximum value \\
${ }^{90} \mathrm{Sr}$ & 25.3 & 96 \\
${ }^{137} \mathrm{Cs}$ & 53 & 230 \\
${ }^{238} \mathrm{Pu}$ & 0.12 & 0.52 \\
${ }^{239,240} \mathrm{Pu}$ & 0.25 & 0.94 \\
${ }^{241} \mathrm{Am}$ & 0.67 & 2.5 \\
${ }^{241} \mathrm{Pu}$ & 9.24 & 40 \\
\hline
\end{tabular}


Table 3. Exposure dose rates at the experimental sites in June 2008, $\mu \mathrm{Sv} \mathrm{h}^{-1}$.

\begin{tabular}{cccc}
\hline Statistical parameter & Site \# 1 & Site \# 2 & Site \# 3 \\
\hline Mean arithmetic value & 2.5 & 4.09 & 0.48 \\
Standard deviation & 1.77 & 3.32 & 0.29 \\
Kurtosis & 1.42 & -1.41 & -1.08 \\
Skewness & 0.99 & 0.2 & 0.5 \\
Mean geometric value & 1.85 & 2.15 & 0.39 \\
Standard geometric deviation & 2.36 & 3.91 & 1.98 \\
Range & $0.25-9.47$ & $0.17-10.4$ & $0.10-1.27$ \\
Sampling size & 108 & 104 & 120 \\
\hline
\end{tabular}


Table 4. ${ }^{137} \mathrm{Cs}$ and ${ }^{90} \mathrm{Sr}$ concentrations in soils in the terrestrial areas of the ChNPP cooling pond shoreline ecosystem in 2007-2008, kBq/kg.

\begin{tabular}{|c|c|c|c|c|c|c|c|c|}
\hline \multirow{2}{*}{$\begin{array}{c}\text { Experimental } \\
\text { Site }\end{array}$} & \multicolumn{4}{|c|}{${ }^{137} \mathrm{Cs}$} & \multicolumn{4}{|c|}{${ }^{90} \mathrm{Sr}$} \\
\hline & $\begin{array}{c}\text { Geometric } \\
\text { mean }\end{array}$ & $\begin{array}{c}\text { Standard } \\
\text { geometric } \\
\text { deviation }\end{array}$ & Range & $n$ & $\begin{array}{c}\text { Geometric } \\
\text { mean }\end{array}$ & $\begin{array}{c}\text { Standard } \\
\text { geometric } \\
\text { deviation }\end{array}$ & Range & $n$ \\
\hline Site \# 1 & 14.3 & 2.5 & $\begin{array}{c}3.4-62.8 \\
0.1-\end{array}$ & 12 & 6.5 & 4 & $0.3-53.3$ & 12 \\
\hline Site \# 2 & 7.9 & 13.6 & 107.0 & 12 & 5.8 & 8.2 & $0.1-52.6$ & 12 \\
\hline Site \# 3 & 1.9 & 3 & $0.1-6.3$ & 12 & 1 & 2.3 & $0.2-3.2$ & 12 \\
\hline
\end{tabular}


Table 5. ${ }^{90} \mathrm{Sr}$ and ${ }^{137} \mathrm{Cs}$ concentrations in the biota at experimental site $\# 1, \mathrm{kBq} \mathrm{kg}^{-1}$.

\begin{tabular}{|c|c|c|c|c|c|c|c|}
\hline \multirow[t]{2}{*}{ Biota } & \multirow[t]{2}{*}{ Species } & \multicolumn{3}{|c|}{${ }^{90} \mathrm{Sr}$} & \multicolumn{3}{|c|}{${ }^{137} \mathrm{Cs}$} \\
\hline & & $\begin{array}{l}\text { Geometric } \\
\text { mean }\end{array}$ & $\begin{array}{c}\text { Range of } \\
\text { values }\end{array}$ & $\mathbf{n}$ & $\begin{array}{l}\text { Geometric } \\
\text { mean }\end{array}$ & $\begin{array}{c}\text { Range of } \\
\text { values }\end{array}$ & $\mathbf{n}$ \\
\hline \multirow[t]{2}{*}{ Amphibians } & Rana esculenta & 6.51 & $2.27-55.3$ & 5 & 1.31 & $0.55-4.15$ & 5 \\
\hline & Triturus cristatus & 6.53 & & 1 & & & \\
\hline \multirow[t]{20}{*}{ Birds } & $\begin{array}{l}\text { Acrocephalus } \\
\text { arundinaceus }\end{array}$ & 0.7 & $0.07-6.52$ & 2 & 0.57 & $0.50-0.65$ & 2 \\
\hline & Alcedo attis & 0.18 & $0.06-1.24$ & 4 & 0.48 & $0.22-1.11$ & 4 \\
\hline & Emberiza schoeniclus & 2.47 & $0.28-46.1$ & 3 & 6.7 & $2.22-20.2$ & 2 \\
\hline & Erithacus rubecula & 2.99 & $0.11-21.7$ & 19 & 0.97 & $0.08-3.09$ & 19 \\
\hline & Fringilla coelebs & 5.39 & $0.22-32.5$ & 12 & 2.24 & $0.76-4.91$ & 9 \\
\hline & Lanius collurio & 5.09 & $1.64-15.8$ & 2 & 0.41 & $0.22-0.77$ & 2 \\
\hline & Luscinia luscinia & 3.03 & $0.89-12.8$ & 6 & 0.46 & $0.23-1.37$ & 6 \\
\hline & Motacilla alba & 3.6 & $1.58-8.21$ & 2 & 1.28 & $0.63-2.60$ & 2 \\
\hline & Oriolus oriolus & 0.57 & & 1 & 0.41 & & 1 \\
\hline & Parus coeruleus & 2.18 & $0.93-6.53$ & 3 & 0.69 & $0.36-1.48$ & 3 \\
\hline & Parus cristatus & 11.5 & & 1 & 3.24 & & 1 \\
\hline & Parus major & 3.23 & $0.39-29.7$ & 14 & 0.5 & $0.17-1.11$ & 10 \\
\hline & $\begin{array}{l}\text { Phoenicurus } \\
\text { phoenicurus }\end{array}$ & 50.9 & & 1 & 3.22 & & 1 \\
\hline & Phylloscopus collybita & 0.61 & $0.61-0.61$ & 2 & 1.12 & $0.74-1.71$ & 2 \\
\hline & Phylloscopus trochilus & 7.43 & $3.59-30.9$ & 3 & 1.1 & $0.60-2.80$ & 3 \\
\hline & Sylvia atricapilla & 0.66 & $0.07-4.95$ & 5 & 1.78 & $0.06-7.12$ & 7 \\
\hline & Sylvia borin & 5.17 & & 1 & 1.16 & & 1 \\
\hline & Sylvia communis & 1.9 & & 1 & 0.04 & & 1 \\
\hline & Turdus merula & 1.7 & $0.68-3.19$ & 4 & 0.8 & $0.18-2.47$ & 4 \\
\hline & Turdus philomelos & 3.42 & $0.38-16.4$ & 5 & 5.9 & $0.77-22.9$ & 5 \\
\hline \multirow[t]{8}{*}{ Small mammals } & Apodemus agrarius & 0.57 & $0.22-1.04$ & 5 & 3.35 & $1.37-8.68$ & 6 \\
\hline & Micromys minutes & 3.33 & $2.95-3.75$ & 2 & 6.9 & $4.24-11.3$ & 2 \\
\hline & Microtus spp & 13.5 & $10.9-16.7$ & 2 & 0.67 & $0.49-0.94$ & 2 \\
\hline & Myodes glareolus & 9.6 & $2.35-32.1$ & 18 & 6.46 & $1.60-49.2$ & 18 \\
\hline & Sorex araneus & 3.73 & $2.31-4.98$ & 4 & 3.97 & $0.99-13.8$ & 4 \\
\hline & Sorex minutes & 35.5 & & 1 & 0.71 & & 1 \\
\hline & Sylvaemus flavicollis & 7.38 & $3.56-15.0$ & 4 & 6.56 & $5.50-8.78$ & 4 \\
\hline & Sylvaemus sp & 4.62 & $2.85-7.48$ & 2 & 2.64 & $0.67-10.5$ & 2 \\
\hline Reptilians & Natrix natrix & 7.02 & $6.30-7.81$ & 2 & 12.4 & $7.99-19.4$ & 2 \\
\hline $\begin{array}{l}\text { Plants, } \\
\text { Herbaceous } \\
\text { (gramineous) }\end{array}$ & On the average & 42.9 & $18.6-109$ & 8 & 2.14 & $0.41-52.7$ & 8 \\
\hline
\end{tabular}


Table 6. ${ }^{90} \mathrm{Sr}$ and ${ }^{137} \mathrm{Cs}$ concentrations in the biota at experimental site \#2, Bq g ${ }^{-1}$.

\begin{tabular}{|c|c|c|c|c|c|c|c|}
\hline \multirow[t]{2}{*}{ Biota } & \multirow[t]{2}{*}{ Species } & \multicolumn{3}{|c|}{${ }^{90} \mathrm{Sr}$} & \multicolumn{3}{|c|}{${ }^{137} \mathrm{Cs}$} \\
\hline & & $\begin{array}{c}\text { Geometric } \\
\text { mean }\end{array}$ & $\begin{array}{c}\text { Range of } \\
\text { values }\end{array}$ & $n$ & $\begin{array}{c}\text { Geometric } \\
\text { mean }\end{array}$ & $\begin{array}{c}\text { Range of } \\
\text { values }\end{array}$ & $n$ \\
\hline Amphibians & Rana terrestris & 32.1 & & 1 & 20.5 & & 1 \\
\hline \multirow[t]{11}{*}{ Birds } & Acrocephalus arundinaceus & 1.4 & $0.16-3.26$ & 9 & 0.31 & $0.02-1.82$ & 10 \\
\hline & Emberiza schoeniclus & 0.84 & & 1 & 0.14 & & 1 \\
\hline & Erithacus rubecula & 3.51 & $1.60-6.41$ & 7 & 2.5 & $1.45-3.59$ & 7 \\
\hline & Fringilla coelebs & 8.38 & $5.05-12.6$ & 3 & 0.92 & $0.72-1.04$ & 3 \\
\hline & Luscinia luscinia & 6.06 & $2.36-15.6$ & 4 & 1.95 & $1.29-3.31$ & 4 \\
\hline & Parus coeruleus & 4.5 & $2.29-8.83$ & 2 & 3.53 & $2.52-4.93$ & 2 \\
\hline & Parus major & 4.36 & $1.57-12.8$ & 7 & 0.66 & $0.27-1.26$ & 7 \\
\hline & Sylvia atricapilla & 0.66 & $0.07-2.30$ & 7 & 1.33 & $0.90-2.16$ & 7 \\
\hline & Sylvia borin & 2.64 & $0.52-23.2$ & 5 & 1.46 & $1.17-2.01$ & 5 \\
\hline & Turdus merula & 1.74 & $0.39-6.06$ & 5 & 1.88 & $1.10-2.96$ & 5 \\
\hline & Turdus pilaris & 0.37 & & 1 & 0.95 & & 1 \\
\hline \multirow{7}{*}{$\begin{array}{l}\text { Small } \\
\text { mammals }\end{array}$} & Apodemus agrarius & 4.86 & $0.52-22.0$ & 1 & 1.71 & $0.29-16.8$ & 15 \\
\hline & Microtus spp & 8.3 & $4.90-14.1$ & $\begin{array}{l}5 \\
2\end{array}$ & 5.9 & $4.55-7.66$ & 2 \\
\hline & Myodes glareolus & 14.8 & $4.51-29.0$ & 9 & 23.9 & $\begin{array}{c}2.43- \\
151.7\end{array}$ & 9 \\
\hline & Sorex araneus & 7.5 & $3.63-15.5$ & 2 & 4.69 & $3.23-6.81$ & 2 \\
\hline & Sorex minutes & 9.37 & $7.38-11.9$ & 2 & 7.97 & $6.05-10.5$ & 2 \\
\hline & Sylvaemus flavicollis & 11.8 & $1.33-25.2$ & 9 & 7.75 & $0.78-60.0$ & 9 \\
\hline & Sylvaemus sylvaticus & 55.2 & & 1 & 2.15 & & 1 \\
\hline Reptilians & Natrix natrix & 1.25 & $0.42-3.77$ & 2 & 2.79 & $1.35-5.77$ & 2 \\
\hline $\begin{array}{l}\text { Plants, } \\
\text { Herbaceous } \\
\text { (gramineous) }\end{array}$ & On the average & 88.2 & $3.38-236$ & 1 & 2.42 & $1.22-10.3$ & 11 \\
\hline
\end{tabular}


Table 7. ${ }^{90} \mathrm{Sr}$ and ${ }^{137} \mathrm{Cs}$ concentrations in the biota at experimental site \#3, $\mathrm{kBq} \mathrm{kg}^{-1}$.

\begin{tabular}{|c|c|c|c|c|c|c|c|}
\hline \multirow[t]{2}{*}{ Biota } & \multirow[t]{2}{*}{ Species } & \multicolumn{3}{|c|}{${ }^{90} \mathrm{Sr}$} & \multicolumn{3}{|c|}{${ }^{137} \mathrm{Cs}$} \\
\hline & & $\begin{array}{c}\text { Geometric } \\
\text { mean }\end{array}$ & $\begin{array}{c}\text { Range of } \\
\text { values }\end{array}$ & $n$ & $\begin{array}{c}\text { Geometric } \\
\text { mean }\end{array}$ & $\begin{array}{c}\text { Range } \\
\text { of values }\end{array}$ & $n$ \\
\hline \multirow[t]{13}{*}{ Birds } & $\begin{array}{l}\text { Acrocephalus } \\
\text { arundinaceus }\end{array}$ & 1.03 & $0.60-1.63$ & 6 & 0.27 & $0.01-1.33$ & 6 \\
\hline & Acrocephalus palustris & 3.5 & & 1 & & & \\
\hline & Dendrocopus major & 0.22 & $0.08-0.59$ & 2 & 0.09 & $0.05-0.16$ & 2 \\
\hline & Erithacus rubecula & 1 & $0.10-4.13$ & 7 & 0.32 & $0.12-0.60$ & 7 \\
\hline & Fringilla coelebs & 1.44 & $0.78-2.66$ & 2 & 0.2 & $0.20-0.21$ & 2 \\
\hline & Lanius collurio & 1.6 & $0.53-12.6$ & 6 & 0.17 & $0.09-0.25$ & 5 \\
\hline & Luscinia luscinia & 1.13 & $0.24-3.03$ & 7 & 0.23 & $0.10-0.48$ & 7 \\
\hline & Parus coeruleus & 0.77 & & 1 & 1.63 & & 1 \\
\hline & Parus major & 0.81 & $0.33-1.28$ & 3 & 0.31 & $0.15-0.55$ & 3 \\
\hline & Parus polustris & 12.1 & & 1 & 0.5 & & 1 \\
\hline & Sylvia nisoria & 8.26 & $1.45-46.9$ & 2 & & & \\
\hline & Turdus merula & 0.34 & $0.16-0.51$ & 5 & 0.2 & $0.09-0.43$ & 5 \\
\hline & Turdus philomelos & 0.81 & & 1 & 0.84 & & 1 \\
\hline \multirow{7}{*}{$\begin{array}{l}\text { Small } \\
\text { mammals }\end{array}$} & Apodemus agrarius & 1.25 & $0.33-2.81$ & 1 & 1.04 & $0.35-5.88$ & 1 \\
\hline & Crocidura suaveolens & 12 & & 1 & 0.95 & & 1 \\
\hline & Microtus spp & 1.73 & & 1 & 0.3 & & 1 \\
\hline & Myodes glareolus & 1.05 & $0.26-3.58$ & $\begin{array}{l}1 \\
3\end{array}$ & 1.15 & $0.14-8.13$ & $\begin{array}{l}1 \\
3\end{array}$ \\
\hline & Sorex araneus & 2.96 & $1.62-5.40$ & 2 & 0.81 & $0.71-0.93$ & 2 \\
\hline & Sylvaemus flavicollis & 1 & & 1 & 1.48 & & 1 \\
\hline & Sylvaemus sylvaticus & 5.1 & $2.89-8.43$ & 6 & 3.36 & $0.32-14.8$ & 6 \\
\hline \multirow[t]{2}{*}{ Reptilians } & Lacerta agilis & 1.93 & & 1 & 0.43 & & 1 \\
\hline & Natrix natrix & 0.35 & $0.22-0.57$ & 2 & 0.45 & $0.30-0.67$ & 2 \\
\hline $\begin{array}{l}\text { Plants, } \\
\text { Herbaceous } \\
\text { (gramineous) }\end{array}$ & On the average & 7.42 & $0.97-32.1$ & 1 & 0.52 & $0.12-10.9$ & 1 \\
\hline
\end{tabular}


Table 8. Average concentrations $\left(A_{b}\right)$ of ${ }^{90} \mathrm{Sr}$ and ${ }^{137} \mathrm{Cs}$ for combined biota groups, $\mathrm{kBq} \mathrm{kg}^{-1}$.

\begin{tabular}{|c|c|c|c|c|c|c|c|c|}
\hline & \multicolumn{3}{|c|}{${ }^{137} \mathrm{Cs}$} & \multicolumn{5}{|c|}{${ }^{90} \mathrm{Sr}$} \\
\hline & $\begin{array}{l}\text { Geometric } \\
\text { mean }\end{array}$ & $\begin{array}{l}\text { Geometric } \\
\text { standard } \\
\text { deviation }\end{array}$ & Range & $n$ & $\begin{array}{c}\text { Geometric } \\
\text { mean }\end{array}$ & $\begin{array}{l}\text { Geometric } \\
\text { standard } \\
\text { deviation }\end{array}$ & Range & $n$ \\
\hline \multicolumn{9}{|l|}{$\begin{array}{l}\text { Experimental } \\
\text { Site \# } 1\end{array}$} \\
\hline $\begin{array}{l}\text { Herbaceous } \\
\text { plants }\end{array}$ & 2.1 & 4.7 & $0.4-52.7$ & 8 & 42.9 & 2 & $18.6-109.1$ & 8 \\
\hline Mammals & 5 & 3.6 & $0.5-49.2$ & 24 & 3.9 & 3.6 & $0.2-35.5$ & 23 \\
\hline Small birds & 1 & 3.3 & $0.04-22.9$ & 85 & 2.6 & 4.8 & $0.1-50.8$ & 91 \\
\hline \multicolumn{9}{|c|}{$\begin{array}{l}\text { Experimental } \\
\text { Site \# } 2\end{array}$} \\
\hline $\begin{array}{l}\text { Herbaceous } \\
\text { plants }\end{array}$ & 2.4 & 1.8 & $1.2-10.3$ & 11 & 88.2 & 3.4 & $3.4-235.5$ & 11 \\
\hline Mammals & 9.4 & 5.1 & $0.4-151.7$ & 18 & 12.5 & 2.1 & $1.3-25.2$ & 18 \\
\hline Small birds & 1.7 & 1.6 & $0.7-4.9$ & 28 & 2.8 & 3.5 & $0.1-23.2$ & 28 \\
\hline \multicolumn{9}{|c|}{$\begin{array}{l}\text { Experimental } \\
\text { Site \# } 3\end{array}$} \\
\hline $\begin{array}{l}\text { Herbaceous } \\
\text { plants }\end{array}$ & 0.5 & 3.9 & $0.1-10.9$ & 12 & 7.4 & 3.1 & $1.0-32.1$ & 12 \\
\hline Mammals & 1.7 & 3.5 & $0.3-14.8$ & 21 & 2.5 & 2.4 & $0.3-12.0$ & 21 \\
\hline Small birds & 0.3 & 2.4 & $0.01-1.3$ & 27 & 1.3 & 3 & $0.2-46.9$ & 31 \\
\hline
\end{tabular}


Table 9. Average ${ }^{90} \mathrm{Sr}$ and ${ }^{137} \mathrm{Cs}$ concentration ratios $\left(C R=A_{b} / A_{s}\right)$ for the biota of the ChNPP cooling pond terrestrial ecosystem in 2007-2008, $\left(\mathrm{kBq} \mathrm{kg}^{-1}\right.$ per kBq kg-1).

\begin{tabular}{|c|c|c|c|c|c|c|c|c|}
\hline \multirow{2}{*}{$\begin{array}{c}\text { Groups of } \\
\text { biota } \\
\text { objects }\end{array}$} & \multicolumn{4}{|c|}{${ }^{90} \mathrm{Sr}$} & \multicolumn{4}{|c|}{${ }^{137} \mathrm{Cs}$} \\
\hline & $\begin{array}{l}\text { Geometric } \\
\text { mean }\end{array}$ & $\begin{array}{l}\text { Geometric } \\
\text { standard } \\
\text { deviation }\end{array}$ & Range & $n$ & $\begin{array}{l}\text { Geometric } \\
\text { mean }\end{array}$ & $\begin{array}{l}\text { Geometric } \\
\text { standard } \\
\text { deviation }\end{array}$ & Range & $n$ \\
\hline $\begin{array}{l}\text { Herbaceous } \\
\text { (gramineous) } \\
\text { plants }\end{array}$ & 9.74 & 3.06 & $\begin{array}{l}1.14- \\
295.8\end{array}$ & 31 & 0.28 & 6.45 & $0.02-30.2$ & 31 \\
\hline Amphibians & 1.28 & 3.34 & $0.35-8.50$ & 7 & 0.16 & 4.65 & $0.04-2.59$ & 6 \\
\hline Reptilians & 0.53 & 3.05 & $0.07-1.90$ & 7 & 0.38 & 2.23 & $0.16-1.35$ & 7 \\
\hline Birds & 0.5 & 4.23 & $0.01-45.3$ & 186 & 0.1 & 3.06 & $\begin{array}{c}0.003- \\
1.59\end{array}$ & 177 \\
\hline Mammals & 1.25 & 3.03 & $0.03-11.6$ & 100 & 0.57 & 3.92 & $0.03-19.2$ & 101 \\
\hline
\end{tabular}


Table 10. Concentration of plutonium isotopes in the soil and herbaceous plants at the experimental sites in 2007-2008, kBq kg-1.

\begin{tabular}{|c|c|c|c|c|c|c|c|c|}
\hline \multirow[b]{2}{*}{ Object of study } & \multicolumn{3}{|c|}{${ }^{239,240} \mathrm{Pu}$} & \multirow[b]{2}{*}{$n$} & \multicolumn{4}{|c|}{${ }^{238} \mathrm{Pu}$} \\
\hline & $\begin{array}{c}\text { Geometric } \\
\text { mean }\end{array}$ & $\begin{array}{l}\text { Geometric } \\
\text { standard } \\
\text { deviation }\end{array}$ & Range & & $\begin{array}{c}\text { Geometric } \\
\text { mean }\end{array}$ & $\begin{array}{l}\text { Geometric } \\
\text { standard } \\
\text { deviation }\end{array}$ & Range & $n$ \\
\hline \multicolumn{9}{|l|}{$\begin{array}{c}\text { Experimental } \\
\text { Site \# } 1\end{array}$} \\
\hline Soil & 143.1 & 2.83 & $\begin{array}{l}39.5- \\
699.8\end{array}$ & 6 & 63.5 & 2.76 & $18.1-286.2$ & 3 \\
\hline $\begin{array}{l}\text { Herbaceous } \\
\text { (gramineous) } \\
\text { plants }\end{array}$ & 1.22 & 2.28 & $\begin{array}{c}0.473- \\
1.99\end{array}$ & 3 & 0.513 & 1.96 & $\begin{array}{c}0.236- \\
0.759\end{array}$ & 3 \\
\hline \multicolumn{9}{|l|}{$\begin{array}{c}\text { Experimental } \\
\text { Site \# } 2\end{array}$} \\
\hline Soil & 63.9 & 8.29 & $\begin{array}{l}1.12- \\
270.3\end{array}$ & 6 & 24.8 & 8.8 & $\begin{array}{c}0.386- \\
107.8\end{array}$ & 6 \\
\hline $\begin{array}{l}\text { Herbaceous } \\
\text { (gramineous) } \\
\text { plants }\end{array}$ & 2.85 & 3.16 & $\begin{array}{l}0.809- \\
7.71\end{array}$ & 3 & 1.19 & 3.54 & $0.298-3.54$ & 3 \\
\hline \multicolumn{9}{|l|}{$\begin{array}{c}\text { Experimental } \\
\text { Site \# } 3\end{array}$} \\
\hline Soil & 22.8 & 4.16 & $1.71-82.0$ & 6 & 10.5 & 4.23 & $\begin{array}{c}0.746- \\
37.64\end{array}$ & 6 \\
\hline $\begin{array}{l}\text { Herbaceous } \\
\text { (gramineous) } \\
\text { plants }\end{array}$ & 0.932 & 1.74 & $\begin{array}{c}0.633- \\
1.75\end{array}$ & 3 & 0.532 & 1.61 & $\begin{array}{c}0.380- \\
0.917\end{array}$ & 3 \\
\hline
\end{tabular}


Table 11. Dose rates and risk assessments for the reference species (ERICA) from the radionuclides measured at experimental site \#1 (risk = total dose/reference dose of 40 $\mu \mathrm{Gy} \mathrm{h} \mathrm{h}^{-1}$ for animals and $400 \mu \mathrm{Gy} \mathrm{h} \mathrm{h}^{-1}$ for plants).

\begin{tabular}{|c|c|c|c|c|c|c|c|}
\hline \multirow{2}{*}{ Species } & \multicolumn{5}{|c|}{ Dose, $\mu \mathrm{Gy} \mathrm{h} \mathbf{h}^{-1}$} & \multicolumn{2}{|c|}{ Risk assessment* } \\
\hline & ${ }^{90} \mathrm{Sr}$ & ${ }^{137} \mathrm{Cs}$ & ${ }^{238} \mathbf{P u}$ & ${ }^{239,240} \mathbf{P u}$ & Total & Average & Conservative \\
\hline Herbaceous plants & 0.69 & 2.96 & 0.03 & 0.06 & 3.74 & 0.01 & 0.03 \\
\hline Amphibians & 3.16 & 2.72 & 0.05 & 0.1 & 6.04 & 0.15 & 0.45 \\
\hline Reptilians & 45.9 & 10.3 & 0.05 & 0.1 & 56.3 & 1.41 & 4.22 \\
\hline Birds & 2.25 & 3.61 & 0.05 & 0.1 & 6.01 & 0.15 & 0.45 \\
\hline Mammals (rats) & 7.01 & 9.78 & 0.05 & 0.1 & 16.9 & 0.42 & 1.27 \\
\hline
\end{tabular}

* Conservative estimates of the risk quotient are obtained by multiplying the expected risk quotient by an uncertainty factor of 3. 
Table 12. External dose rates at experimental site \#1, $\mu \mathrm{Gy} \mathrm{h}{ }^{-1}$.

\begin{tabular}{lcccc}
\hline \multicolumn{1}{c}{ Species } & ${ }^{90} \mathrm{Sr}$ & ${ }^{137} \mathrm{Cs}$ & ${ }^{238} \mathrm{Pu}$ & ${ }^{239,240} \mathrm{Pu}$ \\
\hline Herbaceous plants* & $8.45 \times 10^{-7}$ & 1.57 & $8.89 \times 10^{-6}$ & $8.59 \times 10^{-6}$ \\
Amphibians* & $1.04 \times 10^{-7}$ & 1.57 & $4.00 \times 10^{-6}$ & $4.72 \times 10^{-6}$ \\
Reptilians * & $9.75 \times 10^{-8}$ & 1.57 & $3.81 \times 10^{-6}$ & $4.44 \times 10^{-6}$ \\
Birds (duck)* & $1.04 \times 10^{-7}$ & 1.57 & $4.00 \times 10^{-6}$ & $4.58 \times 10^{-6}$ \\
Mammals(rats)* & $7.80 \times 10^{-7}$ & 4 & $8.89 \times 10^{-6}$ & $1.03 \times 10^{-5}$ \\
Small passerine birds & $1.30 \times 10^{-8}$ & 1.38 & $3.89 \times 10^{-7}$ & $1.42 \times 10^{-6}$ \\
Song thrushes & $1.30 \times 10^{-8}$ & 1.37 & $3.88 \times 10^{-7}$ & $1.42 \times 10^{-6}$ \\
Common shrews & $5.48 \times 10^{-7}$ & 2.98 & $7.43 \times 10^{-6}$ & $8.44 \times 10^{-6}$ \\
Small rodents & $5.30 \times 10^{-7}$ & 2.96 & $7.21 \times 10^{-6}$ & $8.42 \times 10^{-6}$ \\
* Asterisks indicate default reference species proposed by the ERICA \\
\multicolumn{5}{l}{ software. }
\end{tabular}


Table 13. Internal dose rates at experimental site \#1, $\mu \mathrm{Gy} \mathrm{h}{ }^{-1}$.

\begin{tabular}{lllll}
\hline Species & ${ }^{\mathbf{9 0}} \mathbf{S r}$ & ${ }^{\mathbf{1 3 7}} \mathbf{C s}$ & ${ }^{238} \mathbf{P u}$ & ${ }^{239,240} \mathbf{P u}$ \\
\hline Herbaceous plants* & 32.3 & 0.56 & 0.029 & 0.062 \\
Amphibians* & 4.91 & 0.34 & 0.019 & 0.04 \\
Reptilians* & 2.07 & 0.92 & 0.001 & 0.001 \\
Birds (duck)* & 2.43 & 0.76 & 0.003 & 0.007 \\
Mammals (rats)* & 5.04 & 1.39 & 0.018 & 0.039 \\
Small passerine birds & 1.92 & 0.22 & 0.003 & 0.007 \\
Song thrushes & 1.95 & 0.23 & 0.003 & 0.007 \\
Common shrews & 4.41 & 1.18 & 0.018 & 0.038 \\
Small rodents & 4.76 & 1.25 & 0.018 & 0.038 \\
\hline * Asterisks indicate default reference species proposed by the ERICA \\
\multicolumn{4}{l}{ software. }
\end{tabular}


Table 14. Assessment of the total dose rates for biota based on the experimental parameters (option 2), $\mu \mathrm{Gy} \mathrm{h} \mathrm{h}^{-1}$.

\begin{tabular}{lcccc}
\hline Species & ${ }^{\mathbf{9 0}} \mathbf{S r}$ & ${ }^{\mathbf{1 3 7}} \mathbf{C s}$ & ${ }^{\mathbf{2 3 8}} \mathbf{P u}$ & ${ }^{239,240} \mathbf{P u}$ \\
\hline Herbaceous plants* & 32.3 & 2.13 & 0.029 & 0.062 \\
Amphibians* & 4.91 & 1.92 & 0.019 & 0.04 \\
Reptilians* & 2.07 & 2.5 & 0.001 & 0.001 \\
Birds (duck)* & 2.43 & 2.33 & 0.003 & 0.007 \\
Mammals (rats)* & 5.04 & 5.39 & 0.018 & 0.039 \\
Small passerine birds & 1.92 & 1.6 & 0.003 & 0.007 \\
Song thrushes & 1.95 & 1.6 & 0.003 & 0.007 \\
Common shrews & 4.41 & 4.16 & 0.018 & 0.038 \\
Small rodents & 4.76 & 4.21 & 0.018 & 0.038 \\
\hline * Asterisks indicate default reference species proposed by the ERICA \\
software.
\end{tabular}


Table 15. Total dose and risk assessment for terrestrial biota species inhabiting the ChNPP Cooling Pond shoreline zone.

\begin{tabular}{|c|c|c|c|c|}
\hline \multirow[t]{2}{*}{ Species } & \multicolumn{2}{|c|}{$\begin{array}{l}\text { Dose for the body, } \\
\qquad \mu G y h^{-1}\end{array}$} & \multicolumn{2}{|c|}{$\begin{array}{c}\text { Risk factor, } \\
\mu G y h^{-1} \text { per } \mu G y h^{-1}\end{array}$} \\
\hline & Option 1 & Option 2 & $\begin{array}{l}\text { Average } \\
\text { value }\end{array}$ & $\begin{array}{c}\text { Conservative } \\
\text { assessment }\end{array}$ \\
\hline Herbaceous plants* & 3.74 & 34.5 & 0.09 & 0.26 \\
\hline Amphibians* & 6.04 & 6.88 & 0.17 & 0.52 \\
\hline Reptilians* & 56.3 & 4.57 & 0.11 & 0.34 \\
\hline Birds (duck)* & 6.01 & 4.78 & 0.12 & 0.36 \\
\hline Mammals (rats)* & 16.9 & 10.5 & 0.26 & 0.79 \\
\hline Small passerine birds & & 3.53 & 0.09 & 0.27 \\
\hline Song thrushes & & 3.56 & 0.09 & 0.27 \\
\hline Common shrews & & 8.63 & 0.22 & 0.65 \\
\hline Small rodents & & 9.03 & 0.23 & 0.68 \\
\hline
\end{tabular}

* Asterisks indicate default reference species proposed by the ERICA software. 
Table 16. ${ }^{90} \mathrm{Sr}$ and $\mathrm{d}^{137} \mathrm{Cs}$ concentration in biota obtained by the ERICA Tool software (predictions) and actual measurements, $\mathrm{kBq} \mathrm{kg}^{-1}$.

\begin{tabular}{|c|c|c|c|c|}
\hline \multirow{2}{*}{ Species } & \multicolumn{2}{|c|}{${ }^{90} \mathrm{Sr}$} & \multicolumn{2}{|c|}{${ }^{137} \mathrm{Cs}$} \\
\hline & Predicted & Actual & Predicted & Actual \\
\hline Herbaceous plants* & 63.3 & 4.29 & 4 & 2.14 \\
\hline Amphibians* & 8.32 & 6.51 & 2.29 & 1.31 \\
\hline Reptilians* & 3.44 & 7.02 & 5.43 & 12.4 \\
\hline Birds (duck)* & 3.86 & - & 4 & - \\
\hline $\begin{array}{l}\text { Mammals (rats)* } \\
\text { Small passerine }\end{array}$ & 8.12 & - & 8.15 & - \\
\hline birds & 3.25 & 3.23 & 1.43 & 0.5 \\
\hline Song thrushes & 3.25 & 3.42 & 1.43 & 5.9 \\
\hline Common shrews & 8.12 & 3.73 & 8.15 & 3.97 \\
\hline Small rodents & 8.12 & 9.6 & 8.15 & 6.46 \\
\hline
\end{tabular}


Table 17. Predicted (conservative) external dose rates for biota exposure to the exposed Cooling Pond bottonm, $\mu \mathrm{Gy} \mathrm{h} \mathrm{h}^{-1}$.

\begin{tabular}{|c|c|c|c|c|c|c|}
\hline \multirow{2}{*}{ Species } & \multicolumn{6}{|c|}{ Radionuclides (the order of magnitude is given in the brackets) } \\
\hline & $\begin{array}{l}{ }^{90} \mathrm{Sr} \\
\left(10^{-6}\right)\end{array}$ & $\begin{array}{l}{ }^{137} \mathrm{Cs} \\
\left(10^{0}\right)\end{array}$ & $\begin{array}{l}{ }^{238} \mathrm{Pu} \\
\left(10^{-6}\right)\end{array}$ & $\begin{array}{c}{ }^{239+240} \mathrm{Pu} \\
\left(10^{-6}\right)\end{array}$ & $\begin{array}{l}{ }^{241} \mathrm{Pu} \\
\left(10^{-6}\right)\end{array}$ & $\begin{array}{l}{ }^{241} \mathrm{Am} \\
\left(10^{-6}\right)\end{array}$ \\
\hline Herbaceous plants* & 12.5 & 25.3 & 72.8 & 122 & 12.8 & 8250 \\
\hline Amphibians* & 1.5 & 25.3 & 32.8 & 56.4 & 10.4 & 6500 \\
\hline Reptilians* & 1.4 & 25.3 & 31.2 & 53.6 & 10 & 6000 \\
\hline Birds (duck)* & 1.5 & 25.3 & 32.8 & 56.4 & 10.4 & 6250 \\
\hline Mammals (rats)* & 11.5 & 64.4 & 72.8 & 122 & 20.8 & 13800 \\
\hline Small passerine birds & 0.2 & 22.1 & 3.2 & 5.7 & 8.1 & 4700 \\
\hline Song thrushes & 0.2 & 22.1 & 3.2 & 5.7 & 8 & 4680 \\
\hline Common shrews & 8.1 & 48 & 60.8 & 105 & 16.5 & 10800 \\
\hline Small rodents & 7.8 & 47.6 & 59 & 102 & 16.3 & 10700 \\
\hline
\end{tabular}

* Asterisks indicate default reference species proposed by the ERICA software. 
Table 18. Predicted (conservative) internal dose rates for biota exposure to the exposed Cooling Pond bottom, $\mu \mathrm{Gy} \mathrm{h} \mathrm{h}^{-1}$.

\begin{tabular}{lcrrrrr}
\hline \multicolumn{1}{c}{ Species } & \multicolumn{5}{c}{ Radionuclides } \\
& ${ }^{90} \mathbf{S r}$ & ${ }^{137} \mathbf{C s}$ & ${ }^{238} \mathbf{P u}$ & ${ }^{239+240} \mathbf{P u}$ & ${ }^{241} \mathbf{P u}$ & ${ }^{241} \mathbf{A m}$ \\
\hline Herbaceous plants* & 477 & 9 & 0.24 & 0.41 & 0.005 & 0.39 \\
Amphibians* & 72.5 & 6.2 & 0.15 & 0.26 & 0.003 & 3.23 \\
Reptilians* & 30.5 & 14.9 & 0.01 & 0.01 & 0 & 3.23 \\
Birds (duck)* & 35.9 & 12.2 & 0.03 & 0.05 & 0.001 & 3.23 \\
Mammals (rats)* & 74.4 & 22.3 & 0.15 & 0.25 & 0.003 & 3.23 \\
Small passerine birds & 28.4 & 3.6 & 0.03 & 0.05 & 0.001 & 3.23 \\
Song thrushes & 28.9 & 3.7 & 0.03 & 0.05 & 0.001 & 3.23 \\
Common shrews & 65.1 & 19 & 0.14 & 0.25 & 0.003 & 3.23 \\
Small rodents & 70.3 & 20.1 & 0.14 & 0.25 & 0.003 & 3.23 \\
\hline
\end{tabular}

* Asterisks indicate default reference species proposed by the ERICA software. 
Table 19. Predicted (conservative) total dose rates and risks for biota exposure to the exposed Cooling Pond bottom.

\begin{tabular}{|c|c|c|c|c|c|c|c|c|}
\hline \multirow{2}{*}{ Species } & \multicolumn{7}{|c|}{ Dose rates, $\mu \mathrm{Gy} \mathrm{h}^{-1}$} & \multirow{2}{*}{ Risk } \\
\hline & ${ }^{90} \mathrm{Sr}$ & ${ }^{137} \mathrm{Cs}$ & ${ }^{238} \mathbf{P u}$ & ${ }^{239,240} \mathrm{Pu}$ & ${ }^{241} \mathbf{P u}$ & ${ }^{241} \mathrm{Am}$ & Total & \\
\hline Herbaceous plants* & 477 & 34.3 & 0.24 & 0.41 & 0.005 & 0.4 & 512 & 1.28 \\
\hline Amphibians* & 72.5 & 31.5 & 0.15 & 0.26 & 0.003 & 3.24 & 108 & 2.69 \\
\hline Reptilians* & 30.5 & 40.2 & 0.01 & 0.01 & 0 & 3.24 & 73.9 & 1.85 \\
\hline Birds (duck)* & 35.9 & 37.5 & 0.03 & 0.05 & 0.001 & 3.24 & 76.7 & 1.92 \\
\hline Mammals (rats)* & 74.4 & 86.7 & 0.15 & 0.25 & 0.003 & 3.25 & 165 & 4.11 \\
\hline Small passerine birds & 28.4 & 25.7 & 0.03 & 0.05 & 0.001 & 3.23 & 57.4 & 1.44 \\
\hline Song thrushes & 28.9 & 25.7 & 0.03 & 0.05 & 0.001 & 3.23 & 57.9 & 1.45 \\
\hline Common shrews & 65.1 & 67 & 0.15 & 0.25 & 0.003 & 3.24 & 136 & 3.39 \\
\hline Small rodents & 477 & 34.3 & 0.24 & 0.41 & 0.005 & 0.4 & 142 & 3.54 \\
\hline
\end{tabular}

* Asterisks indicate default reference species proposed by the ERICA software. 
Table 20. Total average dose rates and risk assessment resulting from each radionuclide for the biota inhabiting the exposed Cooling Pond bottom.

\begin{tabular}{|c|c|c|c|c|c|c|c|c|}
\hline \multirow{2}{*}{ Species } & \multicolumn{7}{|c|}{ Dose exposures, $\mu G y h^{-1}$} & \multirow{2}{*}{ Risk } \\
\hline & ${ }^{90} \mathrm{Sr}$ & ${ }^{137} \mathrm{Cs}$ & ${ }^{238} \mathbf{P u}$ & ${ }^{239,240} \mathrm{Pu}$ & ${ }^{241} \mathbf{P u}$ & ${ }^{241} \mathrm{Am}$ & Total & \\
\hline Herbaceous plants* & 126 & 7.9 & 0.055 & 0.108 & 0.001 & 0.11 & 134 & 0.34 \\
\hline Amphibians* & 19.1 & 7.3 & 0.035 & 0.069 & 0.001 & 0.87 & 27.3 & 0.68 \\
\hline Reptilians* & 8.1 & 9.3 & 0.001 & 0.002 & $<0.001$ & 0.87 & 18.2 & 0.45 \\
\hline Birds (duck)* & 9.5 & 8.7 & 0.006 & 0.012 & $<0.001$ & 0.87 & 19 & 0.48 \\
\hline Mammals (rats)* & 19.6 & 20 & 0.035 & 0.068 & 0.001 & 0.87 & 40.6 & 1.01 \\
\hline Small passerine birds & 7.5 & 5.9 & 0.006 & 0.012 & $<0.001$ & 0.87 & 14.3 & 0.36 \\
\hline Song thrushes & 7.6 & 5.9 & 0.006 & 0.012 & $<0.001$ & 0.87 & 14.4 & 0.36 \\
\hline Common shrews & 17.2 & 15.4 & 0.034 & 0.067 & 0.001 & 0.87 & 33.6 & 0.84 \\
\hline Small rodents & 18.5 & 15.6 & 0.034 & 0.067 & 0.001 & 0.87 & 35.1 & 0.88 \\
\hline
\end{tabular}

* Asterisks indicate default reference species proposed by the ERICA software. 